\title{
Pattern of Energy and Protein Intake among Stunted Children Aged 3-5 Years in Jatinangor
}

\author{
Geraldo Laurus, ${ }^{1}$ Siti Nur Fatimah, ${ }^{2}$ Dida Akhmad Gurnida ${ }^{3}$ \\ ${ }^{1}$ Faculty of Medicine Universitas Padjadjaran, ${ }^{2}$ Department of Internal Medicine Faculty of \\ Medicine Universitas Padjadjaran/Dr. Hasan Sadikin General Hospital Bandung, ${ }^{3}$ Department of \\ Pharmacology and Therapy Faculty of Medicine Universitas Padjadjaran
}

\begin{abstract}
Background: A child's optimal growth can be indicated by many factors, among them is body height, therefore stunting is one of the evidences of undergrowth. Nutrition, on the other hand, is one of variables affecting growth. This study aimed to examine the nutrition intake, in the form of energy, carbohydrate, protein, and fat in stunted children aged 3-5 years in Jatinangor.

Methods: This cross sectional study was carried out in September to October 2014 using the random sampling method. Dietary data from 70 stunted children aged 3-5 years in pre-school and kindegarten located in 9 urban areas in Jatinangor were collected through 3x24 Recall and Food Frequency Questionaire and analyzed.

Results: Mean energy intake was $1113.6 \mathrm{kcal}$ and mean carbohydrate intake was 137.4 grams. Mean protein intake was 38.4 gram and mean fat intake was 38.2 gram. Types of food highly consumed as the source of carbohydrate were white rice and biscuit, and as the source of protein were meatball, sausage, and egg. Highest consumed vegetables, fruits and snack were water spinach, cabbage, watermelon, banana, and milk respectively.

Conclusions: Mean energy intake, mean carbohydrate intake, and mean fat intake are all below the recommended dietary allowance (RDA) 2013 with individual value of mean energy intake is below RDA 2013 for all subjects. Mean protein intake is slightly above RDA 2013. [AMJ.2016;3(3):364- 70]
\end{abstract}

Keywords: Child, nutrition, stunting

\section{Introduction}

The preschool period during developmental task of children should be followed by a good growth function so it can be optimal. Stunting is one of the indications which shows growth is not optimal. ${ }^{1}$ Recent finding suggest that stunting affect a high percentage of children worldwide. ${ }^{2}$ Indonesia Basic Health Research (Riset Kesehatan Dasar, RISKESDAS Indonesia) in 2013 stated that the prevalence of stunted and very stunted children below 5 years old was $19.2 \%$ and $18.0 \%$ respectively. ${ }^{3}$ This should be anticipated because stunting during early childhood would affect a person in later life. ${ }^{4}$

Nutrition intake was one factor that influenced growth. A good nutrition intake, divided into energy and protein, would optimize growth.5 Later, the nutrition intake would be influenced by the sosioeconomical status. ${ }^{6}$ The Recommended Dietary Allowances (RDA) provided by the Indonesian Ministry of Health in 2013 was a tool used to determine the nutritional intake status. ${ }^{7}$

Jatinangor is an area located in West Java and classified as a low socioeconomic area. ${ }^{8}$ There was no specific study which determined the nutritional intake among stunted children in Indonesia. However, there was only one study that stated low socioeconomic area are related to a high prevalence of stunting children. ${ }^{6}$ This study was conducted to determine the intake of energy and protein among stunted children aged $3-5$ years in Jatinangor.

Correspondence: Geraldo Laurus, Faculty of Medicine, Universitas Padjadjaran, Jalan Raya Bandung-Sumedang Km.21, Jatinangor, Sumedang, Indonesia, Phone: +6281806910993 Email: geraldolaurus@yahoo.co.id 
Table 1 Child Subjects Distribution According to Gender and Age

\begin{tabular}{lcc}
\hline \multicolumn{1}{c}{ Characteristics } & N & \% \\
\hline Gender & & \\
Boy & 43 & 61 \\
Girl & 27 & 39 \\
Age (years) & & \\
3 & 2 & 3 \\
4 & 23 & 33 \\
5 & 45 & 64 \\
\hline
\end{tabular}

\section{Methods}

This was a cross sectional study which described the mean intake of energy and protein among stunted children aged 3-5 years in Jatinangor. This study was conducted during September-October 2014. All procedures were approved by the Health Research Ethics Committee, Faculty of Medicine, Universitas Padjadjaran. The study started by selecting one kindergarten in each district in Jatinangor using the random sampling method. Next, each student was asked for an ethics approval, then asked for the date of birth and performed a height measurement, using a Microtoise Staturemeter with $200 \mathrm{~cm}$ measurement capacity with $0.1 \mathrm{~cm}$ precision. The height and birth date were analyzed using the World Health Organization (WHO) anthroplus software to determine whether the subject was stunted, very stunted or normal. Children who were not healthy or under treatment of a chronic disease were excluded in the study. There were 70 subjects included in the study by using this method.

The second data collection was conducted to measure the mean intake and type of food consumed by the subjects. The method used for this second data collection were 3x24 hours Food Recall and Food Frequency Questionnaire. The interviews were carried out to the subjects' parents or primary care guide who accompanied subjects to school. Later on, the data were matched by using the Buku Foto Makanan, Survei Konsumsi Makanan Individu published by the Ministry of Health, Republic of Indonesia. The data were counted in gram, then analyzed using nutrition software. Each mean intake was matched with the RDA provided by the Indonesian Ministry of Health in 2013, published in Peraturan Menteri Kesehatan (Permenkes) nomor 75 tahun 2013. All complete data were finalized using a computer analysis software.

\section{Results}

Based on the subjects' distribution according to gender and age, the subjects were mostly boys (61\%) and 5-year-old (64\%) (Table 1). The highest energy intake in stunted subjects aging 3-5 years in Jatinangor was $1381.5 \mathrm{kcal}$, came from a 5-year-old. The lowest energy intake, $922 \mathrm{kcal}$, came from a 4-year-old. The highest carbohydrate intake in stunted subjects aged 3-5 years in Jatinangor was $180.7 \mathrm{~g}$, came from a 5-year-old. The lowest carbohydrate intake, $87.7 \mathrm{~g}$, came from a 4year-old.

The mean of protein intake in stunted subjects aged 3-5 years in Jatinangor was 38.4 g. The highest protein intake, $58.9 \mathrm{~g}$, came

Table 2 Values of Energy, Carbohydrate, Protein, and Fat Intake

\begin{tabular}{lccccc}
\hline \multicolumn{1}{c}{ Variables } & N & Median & Max & Min & Var \\
\hline Energy Intake (kcal) & 70 & 1090 & 1381 & 922 & 122 \\
Carbohidrate Intake (gram) & 70 & 137 & 181 & 88 & 24 \\
Protein Intake (gram) & 70 & 38 & 59 & 17 & 9 \\
Fat Intake (gram) & 70 & 39 & 68 & 20 & 10 \\
\hline
\end{tabular}


Table 3 Carbohydrate Food Source

\begin{tabular}{lccccc}
\hline \multicolumn{1}{c}{ Food type } & Never & $\begin{array}{c}\mathbf{1 - 3} \text { times a } \\
\text { day }\end{array}$ & $\begin{array}{c}\text { 4-6 times } \\
\text { a week }\end{array}$ & $\begin{array}{c}\text { 1-3 times a } \\
\text { week }\end{array}$ & $\begin{array}{c}\text { 1-3 } \\
\text { times a } \\
\text { month }\end{array}$ \\
\hline Plain Rice & 0 & 70 & 0 & 0 & 0 \\
Cassava & 10 & 7 & 25 & 17 & 11 \\
Fresh Corn & 30 & 5 & 15 & 7 & 13 \\
Potato & 5 & 11 & 3 & 33 & 18 \\
Wet Noodle & 9 & 11 & 24 & 21 & 6 \\
Instant Noodle & 3 & 12 & 38 & 15 & 2 \\
Rice Noodle & 40 & 1 & 6 & 2 & 21 \\
White Bread & 26 & 12 & 17 & 15 & 10 \\
Biscuits & 21 & 25 & 13 & 7 & 4 \\
Rice Flour & 13 & 3 & 35 & 17 & 2 \\
Prawn/Fish Crackers & 8 & 17 & 32 & 5 & 8 \\
Cilembu Sweet Potato & 57 & 0 & 1 & 3 & 9 \\
Cereal & 27 & 4 & 5 & 20 & 14 \\
Wheat Bread & 60 & 0 & 3 & 3 & 4 \\
Sweet Potato & 49 & 1 & 5 & 7 & 8 \\
\hline
\end{tabular}

Table 4 Protein Food Source

\begin{tabular}{lccccc}
\hline \multicolumn{1}{c}{ Food type } & Never & $\begin{array}{c}\mathbf{1 - 3} \text { times a } \\
\text { day }\end{array}$ & $\begin{array}{c}\text { 4-6 times } \\
\text { a week }\end{array}$ & $\begin{array}{c}\text { 1-3 times a } \\
\text { week }\end{array}$ & $\begin{array}{c}\text { 1-3 times a } \\
\text { month }\end{array}$ \\
\hline Meatballs & 5 & 6 & 47 & 9 & 3 \\
Squid & 47 & 1 & 10 & 5 & 7 \\
Chicken & 12 & 3 & 10 & 36 & 9 \\
Beef & 11 & 2 & 6 & 17 & 36 \\
Sausage & 4 & 12 & 38 & 11 & 5 \\
Chicken Egg & 2 & 11 & 41 & 9 & 7 \\
Quail Egg & 33 & 0 & 8 & 8 & 21 \\
Chicken Satay & 13 & 0 & 3 & 12 & 42 \\
Mutton Satay & 65 & 0 & 0 & 3 & 2 \\
Fresh Water Fish (gurame, mas, & 17 & 0 & 16 & 23 & 14 \\
nila, lele, patin) & & & & & \\
Tofu & 2 & 11 & 47 & 6 & 4 \\
Tempeh & 5 & 9 & 39 & 10 & 7 \\
Mung Bean & 8 & 2 & 24 & 28 & 9 \\
Peanut & 13 & 0 & 5 & 46 & 6 \\
Chinese long bean & 16 & 3 & 23 & 21 & 7 \\
\hline
\end{tabular}


Table 5 Vegetables and Fruit types

\begin{tabular}{|c|c|c|c|c|c|}
\hline Food type & Never & $\begin{array}{l}\text { 1-3 times a } \\
\text { day }\end{array}$ & $\begin{array}{l}\text { 4-6 times } \\
\text { a week }\end{array}$ & $\begin{array}{c}\text { 1-3 times a } \\
\text { week }\end{array}$ & $\begin{array}{l}\text { 1-3 times a } \\
\text { month }\end{array}$ \\
\hline Spinach & 12 & 2 & 21 & 25 & 10 \\
\hline Common Bean & 21 & 4 & 17 & 2 & 26 \\
\hline Cassava Leaf & 61 & 0 & 0 & 0 & 9 \\
\hline Mushroom & 11 & 3 & 3 & 36 & 17 \\
\hline Water Spinach & 7 & 5 & 51 & 5 & 2 \\
\hline Cucumber & 4 & 1 & 2 & 13 & 50 \\
\hline Cabbage & 10 & 2 & 36 & 12 & 10 \\
\hline Water Cabbage & 6 & 1 & 21 & 18 & 24 \\
\hline Carrot & 3 & 17 & 15 & 19 & 16 \\
\hline Beansprouts & 16 & 2 & 13 & 21 & 18 \\
\hline Avocado & 21 & 0 & 1 & 18 & 30 \\
\hline Guava & 7 & 2 & 2 & 14 & 45 \\
\hline Wax Apple & 15 & 1 & 17 & 13 & 24 \\
\hline Orange & 2 & 4 & 11 & 19 & 34 \\
\hline Mango & 26 & 0 & 4 & 2 & 38 \\
\hline Cantaloupe & 12 & 0 & 7 & 28 & 23 \\
\hline Banana & 15 & 0 & 11 & 23 & 21 \\
\hline Snakefruit & 34 & 0 & 2 & 1 & 33 \\
\hline Watermelon & 2 & 9 & 27 & 10 & 22 \\
\hline
\end{tabular}

from a 5-year-old. The lowest protein intake, $16.7 \mathrm{~g}$, came from a 3-year-old. The highest fat intake, $68 \mathrm{~g}$, came from a 5-yearold. The lowest fat intake, $19.6 \mathrm{~g}$, came from a 4-year-old (Table 2).

This study also collected additional data on the carbohydrate and protein food source, vegetables, fruits, and snacks which could also affect the mean of energy and protein intake.

The mostly consumed carbohydrate food sources among stunted 3-5 year -old subjects were plain rice, instant noodle, and white bread. Cereals, Cilembu sweet potato, sweet potato, and potato were the least consumed types, or not consumed at all (Table 3).

Meatballs, tofu, tempeh, sausage, and chicken egg were the 5 protein sources with highest consumption. While, seafood such as fresh prawns, squids, and salt water fish were very rarely consumed by children in Jatinangor. Fresh water fish such as gourami, common carp, catfish, and Mozambique tilapia were consumed by stunted $3-5$ year-old children in Jatinangor 3 times a month at most (Table 4).

The types of vegetable with highest consumption were spinach, cabbage, water spinach, and carrot. The fruits with highest consumption were guava, cantaloupe, papaya, and watermelon (Table 5).

The snacks with highest consumption were ice cream, condensed mild, packaged milk, and cheese, on average 2 times a day. Dairy products that were rarely consumed were yogurt and cheese (Table 6).

\section{Discussion}

The frequency of stunted children in this study was in agreement with a study by Bose et al.9 which states that the frequency of stunted children increases with age.9The mean energy intake was still far below the RDA for 4-6 years old children (1660 kcal) and slightly below the RDA for 1-3 years old (1125 kcal). The mean 
Table 6 Types of Snack

\begin{tabular}{lccccc}
\hline \multicolumn{1}{c}{ Food type } & Never & $\begin{array}{c}\mathbf{1 - 3} \text { times a } \\
\text { day }\end{array}$ & $\begin{array}{c}\text { 4-6 times } \\
\text { a week }\end{array}$ & $\begin{array}{c}\text { 1-3 times a } \\
\text { week }\end{array}$ & $\begin{array}{c}\text { 1-3 times a } \\
\text { month }\end{array}$ \\
\hline Ice Cream & 3 & 3 & 24 & 27 & 13 \\
Powdered Milk & 16 & 11 & 29 & 14 & 0 \\
Packaged Milk & 21 & 23 & 6 & 20 & 0 \\
Condensed Milk & 4 & 39 & 20 & 7 & 0 \\
Goat Milk & 68 & 0 & 0 & 0 & 2 \\
Yogurt & 23 & 1 & 1 & 12 & 33 \\
Cheese & 33 & 0 & 2 & 4 & 31 \\
Jelly & 10 & 2 & 2 & 16 & 41 \\
Chocolate & 13 & 4 & 7 & 15 & 31 \\
Baso tahu & 7 & 7 & 14 & 31 & 11 \\
Wafer & 11 & 24 & 31 & 2 & 1 \\
Pudding & 12 & 1 & 4 & 29 & 24 \\
Biscuits & 21 & 25 & 13 & 7 & 4 \\
Ciki box & 2 & 29 & 31 & 5 & 3 \\
Sweet Martabak & 41 & 0 & 0 & 12 & 17 \\
Meat Martabak & 45 & 0 & 2 & 9 & 14 \\
\hline
\end{tabular}

carbohydrate intake of the subjects was still far below the RDA for 4-6 years old children (220 g). This value is also below the RDA for $1-3$ years old children (155 g). The mean protein intake was slightly above the RDA for 4-6 years old (35 g). This is also far above the RDA for 1-3 years old children ( $26 \mathrm{~g}$ ). The mean fat intake of the subjects was far below the RDA for 4-6 years old children (62 g) and the RDA for 1-3 years old children ( $44 \mathrm{~g}$ ).

A study in Egypt has some correlation with this study. The similarities between the two studies are that there are no other diseases or symptoms other than stunting, identical measuring tool for body height, and the same data collection procedure on nutritional intake. The differences are that the study in Egypt $^{10}$ includes subjects of 2 years of age or older and uses a nutritional conversion standard issued by the National Nutrition Institute of Egypt. The similar findings are that the mean energy and fat intake are both below the value recommended by the Egypt's authority. The mean energy and fat intake in the Egyptian study are $927.35 \mathrm{kcal}$ and 25.04 kcal respectively, which are quite different from the result of this study. That study also shows a mean protein intake that is below the recommended value, while this study discovered that the daily protein requirement was met. However, it is similar in the sense that the percentage of protein requirement is the highest compared to energy and fat. ${ }^{10}$ Reddy et al. ${ }^{11}$ have conducted a study in India which discovers a similar result that the prevalence of protein intake fulfillment is slightly higher than other nutrition. ${ }^{11}$ This finding is also supported by a study in Belgium ${ }^{12}$ which states that preschool children have mean nutritional intake that is below the recommended value.

Furthermore, the most consumed carbohydrate food source was the same with the one discovered by a study in Bogor, that were rice and noodles. The most consumed protein food source also conformed to the study in Bogor were milk, eggs, tofu, and tempeh. 
The most consumed vegetables and fruits were water spinach, cabbage, watermelon and banana. The study in Bogor ${ }^{13}$ also discovers carrots and oranges to be two of the most consumed food. The low consumption of carrots and oranges in Jatinangor was probable due to their limited availability compared to the study in Bogor. ${ }^{8}$ The most consumed snack in Jatinangor was also the same with Bogor: milk and biscuits.

The main limitation of this study was that the parents or wardens interviewed in this study were not able to recall the type or amount of food that their children had consumed. This limitation had been minimalized by asking them to take notes on whatever food the children consumed in the last 3 days prior to the interview. Another limitation was the usage of 3x24 hours Food Recall and Food Questionnaire was unable to calculate the absolute amount of energy and protein intake when correlated with certain diseases, and was only able to moderately measure the relative risk and short-term protein intake even though body height was affected by protein intake in a long term. This method was used because compared to other dietary intake interview method, 24 hours recall were recommended to estimate the amount of food taken in a short period of time. ${ }^{14}$

As a conclusion, the mean energy, carbohydrate, and fat intake are all below RDA 2013. The mean protein intake is slightly above RDA 2013. The possible interventions in 3-5 years old children with stunting and unfulfilled RDA can refer to Petunjuk Teknis Pelaksanaan Gizi Buruk (Technical Guidelines for Malnutrition) that was issued by the Program Nasional Pemberdayaan Masyarakat (PNPM). This program starts with case finding and is consecutively followed by management and further examinations, coordination with local health authorities, and lastly by intervention and follow-ups. Food intake and physical activity should also be adjusted so that a child can achieve optimal growth. ${ }^{15}$

\section{References}

1. Golden MH. Proposed recommended nutrient densities for moderately malnourished children. Food Nutr. 2009;30(3):S267-342.

2. de Onis M, Onyango A, Borghi E, Siyam A, Blössner M, Lutter C. Worldwide implementation of the WHO child growth standards. Public Health Nutr. 2012;15(09):1603-10.
3. Badan Penelitian dan Pengembangan Kesehatan Kementerian Kesehatan RI. Riset kesehatan dasar. Jakarta: Badan Penelitian dan Pengembangan Kesehatan Kementerian Kesehatan RI;2013.

4. Walker SP, Chang SM, Powell CA, Simonoff E, Grantham-McGregor SM. Early childhood stunting is associated with poor psychological functioning in late adolescence and effects are reduced by psychosocial stimulation. J Nutr. 2007;137(11):2464-9.

5. Dewey KG, Begum K. Long-term consequences of stunting in early life. Matern Child Nutr. 2011;7(s3):5-18.

6. Ulfani DH, Martianto D, Baliwati YF. Faktorfaktor sosial ekonomi dan kesehatan masyarakat kaitannya dengan masalah gizi underweight, stunted, dan wasted di Indonesia: pendekatan ekologi gizi. Jurnal Gizi dan Pangan. 2011;6(1):59-65.

7. Menteri Kesehatan Republik Indonesia. Peraturan menteri kesehatan Republik Indonesia nomor 75 tahun 2013. Jakarta: Departemen Kesehatan Republik Indonesia; 2013.

8. Badan Pusat Statistik Provinsi Jawa Barat. Jawa Barat Dalam Angka 2012. Jawa Barat: Badan Pusat Statistik Provinsi Jawa Barat; 2012.

9. Bose K, Biswas S, Bisai S, Ganguli S, Khatun A, Mukhopadhyay A, et al. Stunting, underweight and wasting among Integrated Child Development Services (ICDS) scheme children aged 3-5 years of Chapra, Nadia District, West Bengal, India. Matern Child Nutr. 2007;3(3):216-21.

10. Mikhail WZ, Sobhy HM, El-sayed HH, Khairy SA, Salem HYA, Samy MA. Effect of nutritional status on growth pattern of stunted preschool children in Egypt. Academic Journal of Nutrition. 2013;2(1):01-9

11. Reddy CG, Arlappa N, Kumar RH, Kumar S, Brahmam G, Balakrishana N, et al. Diet and nutritional status of rural preschool children in the State of Orissa. J Hum Ecol. 2006;19(3):205-14.

12. Huybrechts I, Matthys C, Vereecken C, Maes L, Temme EH, Van Oyen H, et al. Food intakes by preschool children in Flanders compared with dietary guidelines. Int J Environ Res Public Health. 2008;5(4):24357.

13. Welasasih BD, Wirjatmadi RB. Beberapa faktor yang berhubungan dengan status gizi balita stunting. The Indon $\mathrm{J}$ of $\mathrm{PH}$. 2012;8(3):99-104. 
14. Holmes B, Dick K, Nelson M. A comparison of four dietary assessment methods in materially deprived households in England. Public Health Nutr. 2008;11(05):444-56.
15. Nicklas T, Hayes D. Position of the American Dietetic Association: nutrition guidance for healthy children ages 2 to 11 years. J Am Diet Assoc. 2008;108(6):1038-44. 